\title{
THE USE OF INSTAGRAM AS A MEDIA TO TEACH STUDENTS' WRITING RECOUNT TEXT
}

\author{
Siti Sholikhah, Muh Syafei and Aisyah Ririn Perwikasih Utari \\ Universitas Muria Kudus, Indonesia
}

\begin{abstract}
The objective of this research is to find out whether there is a significant difference between students' writing recount text before and that after being taught by using Instagram as a media or not. In this research, the researcher used quantitative method and used quasi-experiment as the design of the research. The sample consists of 36 students from X MIPA 4 which are taken by using cluster random sampling technique. The researcher uses test as the instrument of the research. The test is in the form of writing test to know the students' writing ability before and after being taught by using Instagram as a media. The result of the research shows that the students' mean score have an improvement from 6.8 to 8.8 and from good categorize to excellent categorize.. The calculation of t-test shows that the $\mathrm{H}_{\mathrm{o}}$ is rejected and $\mathrm{H}_{\mathrm{a}}$ is accepted. In conclusion, there is a significant difference between students' writing recount text before and after being taught by using Instagram as a media.
\end{abstract}

Key words: Instagram, Media, Recount Text, English Writing

\section{INTRODUCTION}

In modern era, the teacher must master how to bring technology as a media in teaching and learning process, especially in teaching and learning English. One of technology that people use every day is social media. Nowadays, one of the most popular social media is Instagram. Moreau (2018:1) notes that "Instagram is social networking app made for sharing photos and videos from smartphone". On Instagram, there are so many feature that the teacher can use to teach the students, especially in teaching writing of recount text. It is because there is a caption place to write something and it could become a media for the students to practice their writing ability. From the students' habit to practice by using Instagram, they can learn how to write a recount text in fun way based on their personal experience.

Instagram helps the students to learn based on the authentic material. It is used by the teacher to support the students' practice in English. Savini (2017) also explained that Instagram becomes interesting and valuable media in her English class. In Practicing English, the students have four abilities to be mastered; they are listening, speaking, reading and writing. From those abilities, writing becomes the most difficult ability to be mastered by the students. López and Campilio (2016:1) noted that "writing is a very complex task". In writing the text, the students not only focus on the sentence' structure or tenses used in a sentence, but also the students must focus on the organization, content, vocabulary and mechanics.

Interview with the students indicated they still have difficulties to arrange the sentence. They rarely practice to write a text by using English language, especially by using past tense, like recount text. In teaching and learning process, the teacher usually uses a media like whiteboard, marker, LCD projector and a textbook. Based on the researchers'observation and interview with the teacher, 
there is a problem in managing the time when the teacher uses those media. To prepare the LCD projector the teacher spends at least 15 minutes. When the teacher uses whiteboard and marker, the teacher has a problem in explaining the material for the students. It is because the teacher needs to write the material on the whiteboard and it takes around 20 minutes. When the teacher explains orally by using textbook, some students cannot understand the material that the teacher has been explained. It is proved when the teacher asks the students some questions related to the material, they cannot answer the teacher's question. And the effect of using those media is that the students only have 15 minutes left to practice their writing ability. For the students that start to learn writing, it is very difficult for them to write something only for 15 minutes. The students usually can write one paragraph for that time and there are still a lot of mistake in their grammar, mechanics, vocabulary, organization and content that they choose for their writing.

From those reasons, the researchers want to use Instagram as a media to learn writing recount text. It can become an authentic material for the students to practice their writing, especially in writing recount text. It also can be an interactive media to teach the students, it is because from the researcher's observation showed that $90 \%$ of students in SMA 2 Kudus use Instagram as their entertainment media to spend their time. They usually write an interesting caption on Instagram about their daily activities. They also can spend a lot of time only for surfing on Instagram and forget to study. To make Instagram has a positive impact for the students; the teacher can use Instagram in teaching writing recount text to get the students' improvement in it. From those explanations, the researchers want to use Instagram as a media to write recount text based on their personal experience at school under title "The Use of Instagram as a Media to Teach Students' Writing Recount Text".

Based on the statement of the research, the objective of the research is "to find out whether or nor there is an significant difference between students' writing recount text before and that after being taught by using Instagram as a media or not".

\section{REVIEW TO RELATED LITERATURE}

\section{Writing Recount Text}

This research deals with students' writing ability using English language. Brown (2013) defined writing as an exclusive skill that people from the past usually used to change the spoken text into written text in order to write a special document like political agreement, business contract and legal document. While Nunan (1991) defined writing as a text that people need to keep a permanent document, instead of spoken text that cannot become a permanent document. From those definitions, it can be concluded that writing is important for documentation. Accordingly, the researchers want to improve the students' writing ability, so they can document their experience from the school. The genre of text that tells about experience is recount text. Barwick (1999) defined that recount text is a text that reconstructs the past events. The recount text tells about 
the past event, so the language feature uses in the text uses past test. Because the students also have difficulties in using a past tense, so the researchers decided to use this genre of the text.

The generic structure of recount text is orientation, event, and re-orientation. Orientation is the beginning of recount text that includes the information about who the character, where the story happen and when the story happen. Events are the sequence of the story; it includes why the story happens and how the story happens. Then, re-orientation is the conclusion from the entire story and represent about the writers' feeling.

Language features of recount text are using nouns and pronouns to identify people, animal, or things. To build up the description, the writer can use large and complex noun. To build the main idea of the recount text, the writers can use word families. And to build word chains, they can use an action verb. The detail information can be described by using descriptive word. The text is written using past tense to show that the text retell the experience or event. The text also uses conjunction and connectives to connect one event with the others.

\section{Instagram as a Media to Teach Writing}

Instagram is a kind of social media to post the photos or videos trough an application to document it. Instagram can become an interactive media for the students to learn English writing ability, especially writing recount text. Akhiar, Mydin and Kasuma (2017) explained that Instagram can become a media for the students to improve their motivation to learn writing. But, the result of the research showed that students got moderate attitudes in using Instagram. They stated that it is because the teacher gets difficult to manage the students when they used it at the class or outside the class. Because of that, the researchers want to improve that research. The researcher does the treatment that is different from the previous ones. In this research, the researcher not only focuses on students' hard skill, but also on students' soft skill. The teaching and learning steps by using Instagram can be seen as follows:

1. The teacher told the students that the teaching and learning will use Instagram.

2. The teacher explained and introduced to the students about the reasons why the teacher had to use Instagram as part of their teaching and learning, as they never used it before in teaching and learning process.

3. The teacher gave a suggestion related to their responsibilities in using smartphone at the class.

4. The teacher asked the students to access the Instagram and opened the teacher account. For the students that not bring their phone, the school facilitated them with laptop and the students can access the Instagram trough the laptop. The teacher had prepared the material about the recount text on teacher's Instagram account the teacher can upload the material trough story or veranda status. When the teacher used statues story to upload the material, the teacher will know which students who had opened the material.

5. The teacher asked the students to observe the example of recount text on Instagram.

6. The teacher asked the students to write a recount text on Instagram. 
7. The students uploaded their assignment on Instagram and completed it with hash tag and tag the teacher's account.

\section{The Difference of Instagram with the Other Social Media}

As we know that Instagram is the social media that was created on October $6^{\text {th }}$ 2010. As usual, when there is a new product, it must have unique thing that will make people interest in using it. It is the same case with Instagram, Kevin Systrom and Mike Kriger also created the new product with the unique things that make people interest in using it. The unique things from Instagram are in its feature.

Instagram gives new and complete features compared with the others social media. In Instagram, people can directly using a photo filter to make the photo ready to post on Instagram and to show how artistic the photos or videos.Based on Rouse (2017) in his article, he explained thatInstagram offers people to upload the video using edited feature as like the photos filter. Besides that, people can change the setting to see who watch or look the photos or videos that they have been shared. We can directly send message to our friends or other using direct massage in Instagram feature. The last, on Instagram we can use a live broadcast.

Instagram is different from others social media because it has the complete and interesting features. Not only that, Instagram also offers us to connect with others social media and also allows us to share photos and videos in the same time in more than one social media site. Because of those reasons, the researcher wants to use Instagram as a media to teach writing and helps the students to improve their English language writing.

\section{RESEARCH METHOD}

This research uses quantitative method. The researchers conducted a quasiexperimental research as the design of the research. The population in this research is tenth grade students of SMA 2 Kudus in academic year 2018/ 2019. In the determining the sample, the researchers used a cluster random sampling as the technique to choose the sample. The sample of this research is 36 students from $\mathrm{X}$ MIPA 4. To measure the variable, the researcher uses test as the Instrument. The instrument to collect the data is writing test. In scoring the test, the researcher uses a scoring rubric from Brown (2003). To collect the data, the researchers used several steps. First, the researchers conduct the Entering pre-test of writing recount text, then giving the treatment by using instagram as a media of teach writing recount text to the students for 4 times, next doing post-test of writing recount text, after that gathering the data from pre and post-test, and the last analyzing the data by using statistical formula.In analysing the data by using hypothesis testing, the researchersused five steps model. First, making assumptions and meeting test requirements. Second, stating the null hypothesis. Third, selecting the sampling distribution and establishing the critical region. Fourth, computing the test statistic and then the last is making decision and interpreting the result of the pre-test and post-test. 


\section{FINDINGS}

The students' pre-test score showed that the minimum score was 5.25 and the higher score was 9.125 . The table of frequency distribution can be seen as follow:

Table 1The Students' Pre-Test Score

\begin{tabular}{|c|c|c|c|}
\hline No. & Score & Frequency (f) & Percentage $(\%)$ \\
\hline 1. & 5.25 & 2 & $6 \%$ \\
\hline 2. & 5.75 & 2 & $6 \%$ \\
\hline 3. & 6.125 & 2 & $6 \%$ \\
\hline 4. & 6.25 & 3 & $8 \%$ \\
\hline 5. & 6.375 & 1 & $3 \%$ \\
\hline 6. & 6.5 & 3 & $8 \%$ \\
\hline 7. & 6.625 & 5 & $14 \%$ \\
\hline 8. & 7 & 4 & $11 \%$ \\
\hline 9. & 7.25 & 2 & $6 \%$ \\
\hline 10. & 7.375 & 4 & $11 \%$ \\
\hline 11. & 7.5 & 3 & $8 \%$ \\
\hline 12. & 7.875 & 2 & $6 \%$ \\
\hline 13. & 8.25 & 1 & $3 \%$ \\
\hline 14. & 8.5 & 1 & $3 \%$ \\
\hline 15. & 9.125 & 1 & $3 \%$ \\
\hline \multicolumn{2}{|c|}{$\Sigma$} & 36 & $100 \%$ \\
\hline
\end{tabular}

Ability before using Instagram shows that the highest score is 9.125 and only $3 \%$ of the students get it, which means only 1 student gets the highest score. And the lowest score is 5.25 and $6 \%$ of the students get it, which means 2 students got the lowest score. While most of the students get 6.625 , and $14 \%$ of the students got that score, which means 5 students get that score. Because most of the students get score on 6.625 , it impacts on the students mean score that is 6.87 .

Based on table above, it shows that students' pre-test score still not evenly distribute. It is also supported with the calculation of the standard deviation that the result is 0.89 . It is higher than the standard deviation of students' post-test score.

After conducting the pre-test and giving the treatment for 4 meetings with the students, the researchers gave the post-test to the students after the researcher doing the treatment by using Instagram as a media to teach students' writing recount text. The explanation can be seen in table below:

Table 2 The Students' Post-Test Score

\begin{tabular}{|c|c|c|c|}
\hline No. & Score & Frequency (f) & Percentage (\%) \\
\hline 1. & 7.5 & 2 & $6 \%$ \\
\hline 2. & 7.875 & 6 & $17 \%$ \\
\hline 3. & 8.25 & 9 & $25 \%$ \\
\hline 4. & 8.625 & 3 & $8 \%$ \\
\hline 5. & 9.125 & 4 & $11 \%$ \\
\hline 6. & 9.5 & 1 & $3 \%$ \\
\hline 7. & 9.625 & 5 & $14 \%$ \\
\hline 8. & 10 & 6 & $17 \%$ \\
\hline \multicolumn{2}{|c|}{$\sum$} & 36 & $100 \%$ \\
\hline
\end{tabular}


Based on the table above, the students' writing test score after the use of Instagram as a media, the data shows that the minimum score is 7.5 and only $6 \%$ of the students get that score, which means only 2 students get the lowest score. While the highest score is 10 and $17 \%$ of the students get it, which means 6 students get the highest score. Most of the students got 8.25 and it is $25 \%$ of the students, which means 9 students got that score. Because of that, it impacts on the students' post-test mean score. The students' post-test mean score is 8.8 and it is in the level of Excellent.

Based on the table above, the data shows that the students' post-test score is well distributed. It is proved from the calculation of the standard deviation that the result is 0.83 . It is less than the standard deviation of the students pre-test score that means the score distribution of the students post-test is well distributed than the pre-test score.

\section{Hypothesis Testing}

In doing the hypothesis testing, the researcher uses five steps model, the steps are:

1. Making assumptions and meeting test requirements

Model: Random samples

Level of measurement is interval

Sampling distribution is normal

2. Stating the null hypothesis

$H_{o}: \mu_{1}=\mu_{2}$

$H_{o}$ : there is no significant difference between students' writing recount text before and after being taught by using Instagram as a media.

3. Selecting the sampling distribution and establishing the critical region

Sampling distribution $: t$ distribution

$\alpha \quad: 0.05$, two-tailed

Degree of freedom $\quad: \mathrm{N}-1$

$\begin{array}{ll} & 36-1=35 \\ \mathrm{t} \text { (critical) } & : \pm 2.042\end{array}$

4. Computing the test statistic

$\mathrm{t}_{\mathrm{o}}($ obtain $)=\frac{\sigma}{\sqrt{\frac{\sum D^{2}-\left(\frac{2 D}{N}\right)^{2}}{N(N-1)}}}$

$\mathrm{t}_{\mathrm{o}}($ obtain $)=5.3$

\begin{tabular}{ccccccccc}
\hline $\mathrm{N}$ & \multicolumn{2}{c}{ Pre-Test } & \multicolumn{2}{c}{ Post-Test } & \multicolumn{3}{c}{ T-Test } \\
\cline { 2 - 9 } & Mean & SD & Mean & SD & df & $\alpha$ & $\mathrm{t}$ (critical) & t (obtain) \\
\hline 36 & 6.8 & 0.89 & 8.8 & 0.83 & 35 & 0.05 & \pm 2.042 & 5.3
\end{tabular}

5. Making decision and interpreting the result of the pre-test and post-test

There are two possibilities decision in this research. They are:

1. Accept $\mathrm{H}_{0}$ and reject $\mathrm{H}_{\mathrm{a}}$ if $\mathrm{t}_{\mathrm{o}}(\mathrm{t}$ obtain) does not fall in the critical region

2. Reject $\mathrm{H}_{\mathrm{o}}$ and accept $\mathrm{H}_{\mathrm{a}}$ if $\mathrm{t}_{\mathrm{o}}$ (t obtain) falls in critical region 
Based on the calculation, it shows that $t$ obtain $\left(t_{0}\right)$ falls in the critical region because the result of t obtain $\left(\mathrm{t}_{\mathrm{o}}\right)$ is more than $t$ critical $\left(\mathrm{t}_{\mathrm{t}}\right)\left(\left(\mathrm{t}_{\mathrm{o}}\right)>\left(\mathrm{t}_{\mathrm{t}}\right)=5.3\right.$ $>2.04)$. It can be concluded that the $\mathrm{H}_{\mathrm{o}}$ rejected and $\mathrm{H}_{\mathrm{a}}$ accepted. Because of that, the research hypothesis shows that there is significant difference between students' writing recount text before and after being taught by using Instagram as a media is accepted. The analysis of the data from descriptive statistics (mean and standard deviation) also shows that there is a significant difference between students' writing recount text before and after being taught by using Instagram as a media.

\section{DISCUSSION}

\section{The Students' Writing Recount Text before being taught by Using Instagram as a Media}

Before the researchers did her research, she did an observation and post-test to know the students' condition before the use of Instagram as a media. The observation and the students' post-test were conducted on Thursday, $21^{\text {st }}$ March 2019. From the researcher observation, the teacher taught the students about recount text, but not in detail explanation. The teacher explained the material orally while sit on their chair. Some students seem they focused, but actually not. It is proved when the researcher asked about their understanding; they did not really understand about what the teacher talking about, that is why the students have difficulties in writing by using past tense. They also did not know how to arrange English sentence correctly. Based on them, they are rarely to practice writing English sentence. The teacher usually more focused on the students' theory instead of students' practice skill. And after the teacher finished in explaining the material, the teacher usually asks them to do an exercise under the material.

There is 90 minutes available for the English class. English taught twice in SMA 2 Kudus, but it is divided into English Wajib and English Minat. While the material of this research was recount text and it included on English Wajib, so the researcher only had once a week to meet the students. From the 90 minutes of English class, for the first meeting, the researcher made it efficient by doing and observation and giving the students post-test. 45 minutes (1 hour lesson) the researcher did observation in the class to know the students' activities in teaching and learning process, then 45 minutes left, the researcher did the post-test with the students.

After the researchs did the post-test, the researchesr found that the students' writing ability is in the level of Good. But, the gap between students' lowest score and highest score are too large, it is proved from the students' with standard deviation that found 0.83 and students minimum score is 5.25 and the maximum score is 9.125 while the students' mean score is 6.8 . To help the students in their writing, the researchers used Instagram as a Media to teach the students' writing recount text. 


\section{The Students' Writing Recount Text after being taught by Using Instagram as a Media}

After doing an observation and post-test with the students in the first meeting, the research did the first treatment on the second meeting. The first treatment conducted on Thursday, $28^{\text {th }}$ March 2019. The researchers had prepared the material on Instagram. In this treatment, the researcher gave a lot of suggestion for the students why they should use Instagram in their teaching and learning and the advantage of it. The students also must understand well the learning objective of the material. So, in this first treatment the researchers kept focus on students' soft skill in using Instagram in teaching and learning process. In this first treatment, some students had a lot of question related to the use of Instagram. In the class, which the researcher chose as the sample, most of the students had a good interest with something unique and they never used it before. It was proved from the students' activeness in asking the question related to the use of Instagram in writing recount text. In this first treatment the researcher as the teacher also discuss a little about the recount text on Instagram. The students are very curious and they directly open their account and searching the recount text on Instagram. After they read it, the teacher asked them to write a paragraph about their other experience at the school as their warming activities and the introduction of using Instagram in learning writing recount text. Seems that some students too interest in it, even the class was over they continue their discussion with their friends and directly wrote a paragraph related to their experience in the school on their own Instagram account. Some students also directly sent me massage trough DM not long after the class was over.

The second treatment was conducted on Thursday, $11^{\text {st }}$ April 2019. The researchers conducted the research on that day because on Thursday, $4^{\text {th }}$ April 2019 the students had a holiday because their senior doing an examination. In second treatment, the researcher gave an example of recount text from Instagram, and then the researchers gave a question for the students about generic structure, language features and the purpose of recount text. The researchers had prepared the material about recount text on Instagram, the students just needed to access the researcher's Instagram account and looked at the material there. After that, the researchers and the students had discussion about recount text. In this second treatment, just like the first treatment the researcher asked the students to find recount text on searching engine on Instagram features and find the example from the other's account writing. The teacher had decided the example from the exact account. The teacher cannot put the example on the teacher's Instagram account, it was because the teacher wanted to give the students an authentic material and they should analyze the grammar used in that writing. In this meeting, the teacher did not use as the role model for the students, but the teacher as the guider to guide them to use the correct grammar and structure of recount text. After having discussion, the teacher asked the students to create the recount text and upload it on Instagram.

The third treatment was conducted on Thursday, $18^{\text {th }}$ April 2019. In third treatment, the researcher gave an example of recount text by asking the students to find it through search engine feature on Instagram just like the previous meeting, 
but the researcher using the different example from the different Instagram account. After the teacher and the students having discussion about the language features of recount text, the teacher asked the students to observe and analyze about language features related to the past tense used in the text that the students created it before. The students might find the V2 in that text and changed it into V1. After that, the students presented their work. Last, the researchers and the students did a discussion again about past tense as the language features of recount text as the evaluation.

The fourth treatment was conducted on Thursday $25^{\text {th }}$ April 2019. In this treatment, the researcher gave a post-test after doing a treatment for 45 minutes. The researcher gave the explanation and the example of recount text that they will create. The students still had a lot of questions related to the use of simple past tense on the recount text. Because of that, the teacher and the students were having a long discussion about it. After the explanation, the students created their recount text on Instagram as the post-test. It was conducted because the researchers wanted to know the students' writing recount text after the use of Instagram.

From the first treatment until the fourth treatment, the researchers always gave an exercise for the students to write their recount text on Instagram. It was because the researcher wants the students to learn step by step and using English language as their habit to do interaction on Instagram account by writing their experience. The researchers also never gave home work for the students, so the students had a lot of time to practice their skill especially their writing skill that they rarely got from the English class. The researchers wanted the students to learn by their self at home or outside the school or classroom by writing their experience at their Instagram account as Instagram can be used every time and no need for the students to prepare pen and paper to write. They also can improve their imagination and inspiration by putting photos or videos in their writing. By using a media that they like and from the theory of language cannot learn directly, but must step by steps and change it as the habit, the researcher can improve students' writing recount text by using Instagram as a Media. It is proved from the students' mean score that got 8.8 and the standard deviation decrease from 8.9 to 8.3 which mean that the students score is well distributed.

\section{The Significant Difference between Students' Writing Recount Text before and after being taught by Using Instagram as a Media}

The students' pre-test and post-test improves from the analysis of mean score, while the standard deviation of the students pre-test and the students post-test is decreased which mean the students' post-test score is well distribute than the students' pre-test. The students' pre-test mean score is 6.8 in the level of good categorize and improves on the students post-test which the mean score is 8.8 and it is in the level of excellent categorize. The students' standard deviation pre-test is 0.89 and decrease becomes 0.83 . From the explanation, it shows that the students' writing recount text after the use of Instagram as a media gets the better result than the students' writing recount text before the use of Instagram. 
Based on the analysis of hypothesis testing by using t-test, it shows that there is a significant difference between students' writing recount text before and after being taught by using Instagram as a media. The data shows that the $t_{t}$ ( $t$ critical) uses in this research is \pm 2.042 , it is because the degree of freedom after the calculation from the total sample of the research minus one is 35 while the alpha uses in this research is 0.05 which mean the accuracy of this research is $95 \%$. Then, the calculation of $t_{o}$ ( $t$ obtain) by using t-test formula is 5.3 which means that $t_{o}$ (obtain) falls in the critical region. Because the $t_{o}$ (obtain) falls in the critical region, the $\mathrm{H}_{\mathrm{o}}$ is rejected and $\mathrm{H}_{\mathrm{a}}$ is accepted which means that the there is a significant difference between students' writing recount text before and after being taught by using Instagram as a media.

\section{CONCLUSION AND SUGGESTION}

\section{Conclusion}

After analyzing the data, the researcher concludes that there is a significant difference between students' writing recount text before and after being taught by using Instagram as a media. It is because, in the level of significant 0.05 or the accuracy of the research $95 \%$ and degree of freedom (df) 35 , the $t$ critical is \pm 2.042 and the $t$ obtain 5.3, the $t$ obtain falls in the critical region. Because the $t-$ obtain falls in the critical region, the $\mathrm{H}_{\mathrm{o}}$ (Null Hypothesis) is rejected and the $\mathrm{H}_{\mathrm{a}}$ (Alternative Hypothesis) is accepted.

The students' mean score before the use of Instagram is in the level of good category and after the use of it, the students mean score is the level of excellent category. Because of that, the researchers conclude that Instagram becomes an effective media to teach students' writing recount text.

\section{Suggestion}

Based on the result of the research, the researchers give suggestion for the student and teacher as follows.

1. The researchers suggest for the students that they can use Instagram as a media for them to improve the writing ability especially in writing recount text by writing their experience on it. But, the students should use it wisely and also take a lot of responsibilities.

2. The teacher can use Instagram as a replacement media to deliver the material. The teacher should have a good management in the classroom and makes sure that the students' understand well how to use Instagram in the class and the material that the teacher wants to teach.

\section{REFERENCES}

Ali, M. (1984). Penelitian Kependididikan Prosedur dan Strategi. Bandung: Angkasa

Arikunto, S. (1997). Prosedur Penelitian: Suatu Pendekatan Praktek Edisi Revisi II. 
Jakarta: Rineka Cipta

Akhiar, A. Mydin, A. and Kasuma, S. A. A,. (2017). Students' perceptions and attitudes towards the use of Instagram in English language writing. Malaysian Journal of Learning and Instruction (MJLI), Special issue on Graduate Students Research on Education, 47-72

Barwick, J. (1999). Targeting text. Singapore: Blake Education.

Brown, H. D. (2003). Language Assessment: Principles and Language Practices. California: Longman.

Burns, A. (2010). Doing Action Research in English Language Teaching. New York and London: Routledge

Handayani, F. (2017). Students' Attitudes toward Using Instagram In Teaching Writing. JURNAL EDUCATIVE: Journal of Educational Studies. 2 (1), 23-29

Healey, J. E. (2005). Statistics. Carolina: Carolina Press

Jiménez-López, M. D. and Rodríguez-Campillo, M. J. (2016). Social Media as a Tool for Teaching Writing. Retrieved from https://library.iated.org/publications/INTED

Listiani, G. (2016). The Effectiveness of Instagram Writing Compared to Teacher Centered Writing to Teach Recount Text to Students with High and Low Motivation. Journal of English Language Teaching, ELT FORUM. $5(1), 1-8$

Moreau, E. (2018). What is Instagram, Anyway? Retrieved from https://www.lifewire.com/what-is-instagram-3486316

Nunan, D. (1991). Language Teaching Methodology. Sydney: Practice Hall

Purnama, A. D. (2017). Incorporating Memes and Instagram to Enhance Student's Participation. LLT (Language and Language Teaching Journal). 20 (1), $1-14$

Rouse, M. (2018). DEFINITION Instagram. Retrieved from https://searchcio.techtarget.com/definition/Instagram

Savini, A. (2017). \#Instaclass: 8 Ideas for Using Instagram in the Classroom. Retrieved from http://www.cambridge.org/elt/blog/2017/05/04/8-ideasusing-instagram/ 
PROMINENT Journal, Volume 2, Number 2, July 2019

Sugiyono. (2015). Metode Penelitian Pendidikan. Bandung: Alfabeta

Yadegarfar, H and Simin, S. (2016). Effects of Using Instagram on Learning Grammatical Accuracy of Word Classes among Iranian Undergraduate TEFL Students. International Journal of Research Studies in Educational Technology. 5 (2), 49-60. 